\title{
PENGARUH BESARNYA PENDAPATAN PEGAWAI TERHADAP TINGKAT KEHADIRAN PEGAWAI DI DINAS PARIWISATA PEMUDA DAN OLAHRAGA KABUPATEN MUARO JAMBI
}

\author{
Mustika $^{1}$ \\ Dosen Tetap Universitas Muhammadiyah Jambi ${ }^{1}$ \\ mustikanabila81@gmail.com \\ Mahmud $^{2}$ \\ Dosen Tetap Universitas Muhammadiyah Jambi ${ }^{2}$ \\ Sundari Cahyati ${ }^{3}$ \\ Mahasiswa Universitas Muhammadiyah Jambi ${ }^{3}$ \\ Ringkasan
}

Penelitian ini bertujuan 1) Untuk mengetahui Perkembangan tingkat pendapatan dan tingkat kehadiran pegawai di Dinas Pariwisata Pemuda dan Olahraga Kabupaten Muaro Jambi 2) Untuk mengetahui pengaruh besarnya pendapatan pegawai terhadap tingkat kehadiran pegawai di Dinas Pariwisata Pemuda dan Olahraga kabupaten Muaro Jambi. Jenis data yang digunakan adalah data primer dan sekunder berdasarkan kurun waktu. Untuk mendeskriftifkan Besarnya pendapatan pegawai terhadap tingkat kehadiran pegawai di dinas pariwisata pemuda dan olahraga kabupaten Muaro Jambi. Penelitian ini dapat disimpulkan bahwa Besarnya pendapatan pegawai berpengaruh positif dan signifikan terhadap tingkat kehadiran pegawai di dinas pariwisata pemuda dan olahraga kabupaten Muaro Jambi.

Kata kunci: Pendapatan, Tingkat Kehadiran, Dinas Pariwisata Pemuda dan Olahraga Kabupaten Muaro Jambi.

\section{PENDAHULUAN}

Setiap organisasi, baik swasta maupun pemerintah pasti mempunyai berbagai tujuan yang ingin di capai. Organisasi akan menggunakan sumber-sumber daya yang ada untuk mencapai tujuannya tersebut. Salah satu sumber daya yang penting adalah manusia (Sinungan, 2009). Sumber daya manusia berfungsi sebagai penggerak sumber daya organisasi yang lain.

Kantor Dinas Pariwisata Pemuda dan Olahraga Kabupaten Muaro Jambi merupakan salah satu organisasi yang dibentuk untuk melaksanakan tugas-tugas pemerintahan, pengaturan, dan pemberian pelayanan kepada masyarakat di bidang pemerintahan, pariwisata, kepemudaan dan olahraga. Untuk melaksanakan tugas pokok diatas, Kantor Dinas Pariwisata Pemuda Dan Olahraga Kabupaten Muaro Jambi mempunyai fungsi perumusan kebijakan teknis berdasarkan kebijakan yang ditetapkan oleh Bupati Muaro Jambi. Dalam menjaga serta meningkatkan kualitas kerja pegawai melalui tingkat kehadiran pemimpin perusahaan harus mampu memberikan penambahan upah/gaji berupa tunjangan yang mengarah pada tingkat kehadiran 
pegawai, agar pegawai tersebut semakin bersemangat dan bertanggung jawab dalam menjalankan tugas.

Menurut (Sadorno Sukirno, 2006) Pendapatan atau upah adalah pendapatan uang yang diterima dan diberikan kepada pegawai berdasarkan prestasi-prestasi yang diserahkan yaitu berupa pendapatan dari profesi yang dilakukan sendiri atau usaha perorangan dan pendapatan dari kekayaan. Besarnya pendapatan seseorang bergantung pada jenis pekerjaan yang dilakukannya. Pada instansi pemerintah penambahan upah harus benar-benar di perhatikan dan diperuntukan untuk pegawai yang memiliki tingkat kehadiran yang tinggi dan kemampuan yang lebih di bandingkan dengan pegawai yang lainnya. Konsep tersebut telah menjadi sasaran sebagian besar pengamatan karena hipotesis hubungan antara besarnya pendapatan pegawai dan tingkat kehadiran pegawai saling berkaitan dan merupakan hal yang dapat dimanipulasi untuk keuntungan organisasi.

Peraturan Mentri Dalam Negri Republik Indonesia Nomor 4 tahun 2013 telah ditentukan jam kerja instansi pemerintah adalah 37 jam 30 menit per minggu, baik untuk lima hari kerja maupun enam hari kerja sesuai yang ditetapkan Kepala Daerah masing-masing. Mengacu pada standar jam kerja yang ditetapkan oleh Kemendagri tersebut,serta jumlah hari kerja yang berlaku di Kantor Dinas Pariwisata Pemuda Dan Olahraga Kabupaten Muaro Jambi adalah lima hari kerja yaitu mulai hari senin sampai dengan hari jum'at, maka jam kerja setiap hari yang harus dilakukan oleh pegawai secara efektif adalah $\geq 7,5$ jam. Namun pada kenyataannya ada beberapa pegawai yang masih bersikap tidak mematuhi jam kerja serta peraturan yang telah ditetapkan. Hal ini didukung dari hasil observasi dilapangan serta wawancara yang telah disampaikan oleh Bapak Muhammad Hafis H. I, SE. selaku Kepala Sekretaris Dinas pada Kantor Dinas Pariwisata Pemuda Dan Olahraga Kabupaten Muaro Jambi. Hal ini menunjukkan bahwa masih rendahnya kesadaran pegawai terhadap pentingnya disiplin kerja yang mengarah pada tingkat kehadiran serta kurang tegasnya atasan dalam pemberian sanksi pelanggaran kepada pegawai yang memiliki tingkat kerendahan dalam hal kehadiran/absensi dimana selama ini pegawai yang tidak disiplin diberi teguran lisan sehingga tidak membuat para pegawai jera.

Tingkat kehadiran sangat perlu di tanamkan di lingkungan kerja, karena apabila pegawai lebih profesional dalam bekerja dan juga meningkat dalam hal kehadiran maka akan berpengaruh positif pada instansin pemerintah. Dan tingkat kehadiran pegawai harus di imbangi dengan penambahan upah kepada pegawai agar mereka merasa di hargai dan di 
apresiasi. Menurut (Rekso prayitno, 2004) Pendapatan pegawai merupakan hasil kerja (usaha atau sebagainya) yang di lakukan oleh pegawai atau jumlah penghasilan yang diterima para pegawai dari instansi pemerintah tempat mereka bekerja yang berupa, gaji pokok, tunjangan tetap, honorarium dan pendapatan lainnya.

Dari beberapa faktor yang mempengaruhi kinerja dalam hal ini di lihat dari tingkat kehadiran pegawai lebih dominan di pengaruhi oleh besarnya tingkat pendapatan pegawai. Maka tujuan dari penelitian ini adalah untuk menganalisis (1) tingkat perkembangan pendapatan pegawai dan tingkat kehadiran pegawai di Dinas Pariwisata Pemuda dan Olahraga Kabupaten Muaro Jambi dan (2) pengaruh besarnnya pendapatan pegawai terhadap tingkat kehadiran pegawai di Dinas Pariwisata Pemuda dan Olahraga Kabupaten Muaro Jambi.

\section{METODE PENELITIAN}

\section{Lokasi Penelitian}

Lokasi penelitian yang dilakukan penulis berada pada Kantor Dinas Pariwisata Pemuda Dan Olahraga Kabupaten Muaro Jambi yang terletak di Jl. Lintas Timur, Kelurahan. Bukit Baling, Kecamatan.Sekernan, Kabupaten Muaro Jambi, Provinsi. Jambi, Kode Pos : 36381

\section{Populasi Dan Sampel}

Salah satu langkah dalam penelitian adalah menentukan obyek yang akan diteliti dan besarnya populasi yang ada. Menurut (Sugiyono, 2001) yang dimaksud dengan populasi adalah wilayah generalisasi yang terdiri atas subyek atau obyek yang mempunyai kualitas dan karakteristik tertentu yang ditetapkan oleh peneliti untuk dipelajari dan kemudian ditarik kesimpulannya. Populasi dalam penelitian ini adalah seluruh pegawai pada Kantor Dinas Pariwisata Pemuda Dan Olahraga Kabupaten Muaro Jambi yang berjumlah 27 orang.

\section{Jenis Dan Sumber Data}

Jenis data 5, aktivitas pegawai, dan data dari tempat penelitian seperti daftar hadir, dan daftar gaji.

\section{Metode Analisis Data}

Metode analisis data yang di pakai dalam penelitian ini adalah metode analisis data deskriptif dan kuantitatif. Selanjutnya untuk kepentingan analisis dan pengujian hipotesis digunakan analisis regresi linear sederhana yang diolah menggunakan program SPSS: menurut (Sugiyono, 2006) persamaan regresi sederhana adalah sebagai berikut:

$$
\mathbf{Y}=\boldsymbol{\alpha}+\boldsymbol{\beta} \mathbf{X}+\mathcal{\varepsilon}
$$

Dimana : 
$\mathrm{Y}=$ variabel terikat

$\mathrm{X}=$ variabel bebas

$\alpha=$ konstanta

$\beta=$ koefisien regresi

$\mathcal{E}=$ standar error

Model ini kemudian diaplikasikan dengan penelitian ini sebagai berikut:

$\mathrm{Y}=$ tingkat kehadiran pegawai

$\mathrm{X}=$ pendapatan pegawai

$\alpha=$ konstanta

$\beta=$ koefisien regresi

$\varepsilon=$ faktor kesalahan (asumsi $=0)$

Dalam penelitian ini peneliti menggunakan analisis data dengan menggunakan analisis statistik regresi linear sederhana dengan beberapa tahapan sebagai berikut :

a) Uji Validitas

Sebuah instrument dikatakan valid apabila mampu mengukur apa yang hendak diukur serta dapat mengungkapkan data dan variabel yang akan diteliti secara tepat. Menurut (Sugiyono, 2012:255) validitas adalah tingkat dimana satu instrumen ukur dapat digunakan untuk mengukur sesuai apa yang diharapkan, dengan kata lain ada kesamaan antara data yang dihasilkan dengan data pada objek yang diteliti. Validitas instrumen data yang dapat ditentukan dengan membandingkan nilairhitung dengan rtabel. Kriteria yang digunakan adalah:

- Jika rhitung $>$ rtabel maka instrument tersebut valid

- Jika rhitung $<$ rtabel maka instrumen tersebut tidak valid

Perhitungan untuk uji validitas ini akan menggunakan software SPSS for Windows.

b) Uji Reliabilitas

Hasil penelitian yang reliabel, bila terdapat kesamaan data dalam waktu yang berbeda. Kalau dalam obyek berwarna merah, maka sekarang dan besok tetap berwarna merah. Instrumen yang reliabel adalah instrumen yang bila digunakan beberapa kali untuk untuk mengukur obyek yang sama, akan menghasilkan data yang sama. 90 Metode uji reliabilitas yang paling sering digunakan adalah Cronbach's Alpha. Pengambilan keputusan untuk uji reliabilitas sebagai berikut:

(1) Cronbach's Alpha $<0,6=$ reliabiltas buruk 
(2) Cronbach's Alpha 0,6 - 0,79= reliabiltas diterima

\section{c) Uji Normalitas}

Pengujian normalitas adalah pengujian tentang kenormalan distribusi data. Asumsi yang harus dimiliki oleh data adalah bahwa data tersebut terdistribusi secara normal. Maksud data terdistribusi secara normal adalah bahwa data akan mengikuti bentuk distribusi normal. Pada prinsipnya normalitas dapat dideteksi dengan melihat penyebaran data (titik) pada sumbu diagonal dari grafik atau dengan melihat histogram dari residualnya. Uji normalitas bertujuan untuk menguji apakah dalam model regresi, variabel terikat dengan variabel bebas keduanya mempunyai distribusi normal atau tidak (Ghozali, 2005:83). Dasar pengambilan keputusan:

(1) Jika data menyebar disekitar garis garis diagonal dan mengikuti arah garis diagonal atau grafik histogramnya menunjukkan distribusi normal, maka model regresi memenuhi asumsi normalitas.

(2) Jika data menyebar jauh dari diagonal atau tidak mengikuti arah garis diagonal atau grafik histogram tidak menunjukkan distribusi normal, maka model regresi tidak memenuhi asumsi normalitas.

d) Uji t

Uji statistik $\mathrm{t}$ digunakan untuk mengukur seberapa jauh pengaruh variabel bebas secara individual dalam menerangkan variasi variabel terikat. Jika nilai thitung lebih besar dari nilai tabel, maka dapat dinyatakan bahwa variabel bebas. Secara individual berpengaruh positif terhadap variabel terikat. Jika nilai signifikansi t 0,05 maka dapat dinyatakan bahwa variabel bebas secara individual berpengaruh signifikan terhadap variabel terikat. Hasil uji ini pada output SPSS dapat dilihat pada tabel Coeffients. Nilai dari uji $\mathrm{t}$ - test dapat dilihat dari p-value (pada kolom sig).

e) Uji Koefisien Determinasi (R Square)

Nilai dari koefisien determinasi digunakan sebagai sumbangan pengaruh yang diberikan oleh variabel bebas $(\mathrm{x})$ terhadap variabel terikat (y). Nilai koefisien determinasi dipakai untuk memprediksi seberapa besar kontribusi pengaruh variabel besarnya pendapatan terhadap variabel tingkat kehadiran pegawai dengan syarat, hasil uji t signifikan. Semakin besar nilai koefisien determinasinya, maka akan semakin kuat pengaruh variabel $\mathrm{x}$ terhadap variabel y, dan sebaliknya, semakin kecil nilai yang ditunjukkan oleh $\mathrm{R}$ Square, maka akan semakin lemah pula pengaruh variabel $\mathrm{x}$ terhadap variabel $\mathrm{Y}$. 


\section{Operasional Variabel}

Sesuai dengan pokok masalah penelitian, maka berikut adalah variabel yang digunakan dalam penelitian yang meliputi:

1) Pendapatan $(\mathrm{X})$

Pendapatan pegawai dalam penelitian ini adalah gaji pokok, tunjangan tetap, honorarium, dan pendapatan lainnya.

2) Tingkat Kehadiran (Y)

Tingkat kehadiran adalah tingkat kehadiran pegawai yang sesuai dengan jam kerja yang berlaku pada Dinas Pariwisata Pemuda dan Olahraga Kabupaten Muaro Jambi, yang di ukur dari jumlah hari kehadiran atau persentase kehadiran.

\section{HASIL PENELITIAN}

\section{Tingkat Perkembangan Pendapatan dan Tingkat Kehadiran Pegawai di Dinas}

\section{Pariwisata Pemuda dan Olahraga Kabupaten Muaro Jambi.}

Seperti yang dikemukakan pada bab terdahulu, bahwa penelitian ini bertujuan untuk mengetahui Bagaimana Tingkat Perkembangan Pendapatan Pegawai dan Tingkat Kehadiran pegawai di Dinas Pariwisata Pemuda dan Olahraga Kabupaten Muaro Jambi. Berdasarkan rumusan masalah pada bab terdahulu, peneliti akan menyajikan hasil data mengenai tingkat perkembangan pendapatan dan tingkat kehadiran pegawai. Adapun rumus perkembangan sebagai berikut:

Keterangan :

$$
\begin{gathered}
G=P t-P o \times 100 \% \\
\text { Po }
\end{gathered}
$$

$\mathrm{G}=$ Growth Rate (Tingkat Perkembangan)

$\mathrm{Pt}=$ Present (Nilai Akhir)

Po $=$ Past (Nilai Awal)

Tabel.1. Tingkat perkembangan pendapatan dan kehadiran pegawai di Dinas Pariwisata Pemuda dan Olahraga Kabupaten Muaro Jambi

\begin{tabular}{|l|l|r|r|r|r|r|r|}
\hline \multirow{2}{*}{$\begin{array}{l}\text { N } \\
\text { o }\end{array}$} & Nama & \multicolumn{2}{|c|}{ Pendapatan } & $\begin{array}{c}\text { Perse } \\
\text { n tase }\end{array}$ & \multicolumn{2}{|c|}{$\begin{array}{c}\text { Tingkat } \\
\text { kehadiran }\end{array}$} & $\begin{array}{c}\text { Perse } \\
\text { n tase }\end{array}$ \\
\cline { 3 - 8 } & & 2015 & 2018 & & 2015 & 2018 & \\
\hline 1 & Drs. Indra Gunawan & 103.750 .784 & 103.750 .784 & 13,46 & 239 & 241 & 2,40 \\
\hline 2 & M. Hafis H. I.,SE & 77.610 .630 & 77.610 .630 & 14,58 & 238 & 239 & 2,38 \\
\hline 3 & Supri Hardi, SE & 69.921 .250 & 69.921 .250 & 14,93 & 234 & 237 & 2,36 \\
\hline 4 & M. Iqbal, SE, ME & 69.813 .380 & 69.813 .380 & 13,83 & 233 & 236 & 2,35 \\
\hline 5 & Hatimah, SE & 75.987 .082 & 75.987 .082 & 16,61 & 236 & 239 & 2,38 \\
\hline
\end{tabular}




\begin{tabular}{|c|l|r|r|r|r|r|c|}
\hline \multirow{2}{*}{$\begin{array}{l}\text { N } \\
\text { o }\end{array}$} & Nama & \multicolumn{2}{|c|}{ Pendapatan } & $\begin{array}{c}\text { Perse } \\
\text { n tase }\end{array}$ & \multicolumn{2}{|c|}{$\begin{array}{c}\text { Tingkat } \\
\text { kehadiran }\end{array}$} & $\begin{array}{c}\text { Perse } \\
\text { n tase }\end{array}$ \\
\cline { 3 - 8 } & & 2015 & 2018 & & 2015 & 2018 & \\
\hline 6 & Eti Supriani, S.STP & 59.925 .340 & 59.925 .340 & 15,61 & 234 & 236 & 2,35 \\
\hline 7 & Azwan, S.Ag & 75.140 .800 & 75.140 .800 & 10,99 & 236 & 238 & 2,37 \\
\hline 8 & Herman Susilo, SE & 69.745 .064 & 69.745 .064 & 15,70 & 235 & 237 & 2,36 \\
\hline 9 & Aswar Muda & 65.788 .250 & 65.788 .250 & 15,74 & 234 & 236 & 2,35 \\
\hline 10 & Deni Eriyanti, S.SN & 59.459 .308 & 59.459 .308 & 16,56 & 232 & 235 & 2,34 \\
\hline 11 & Robi Irwanda, SE. & 62.617 .156 & 62.617 .156 & 15,41 & 233 & 235 & 2,34 \\
& M.SI & & & & & & \\
\hline 12 & Dedi Ismet, S.Pdi & 62.024 .694 & 62.024 .694 & 16,36 & 233 & 235 & 2,34 \\
\hline 13 & Saadah, SE & 55.812 .950 & 55.812 .950 & 14,89 & 231 & 233 & 2,32 \\
\hline 14 & Fahrur Rozi & 61.383 .866 & 61.383 .866 & 17,35 & 233 & 235 & 2,34 \\
\hline 15 & Siska Herlina & 51.819 .980 & 51.819 .980 & 16,40 & 227 & 231 & 2,30 \\
\hline 16 & Bayu Yudha P, & 53.467 .368 & 53.467 .368 & 16,55 & 229 & 232 & 2,31 \\
& S.STP & & & & & & \\
\hline 17 & Hajri & 66.076 .002 & 66.076 .002 & 16,59 & 235 & 237 & 2,36 \\
\hline 18 & Wenti Anggraini & 58.508 .440 & 58.508 .440 & 15,23 & 232 & 234 & 2,33 \\
\hline 19 & Salina, A.Md & 49.663 .042 & 49.663 .042 & 15,92 & 225 & 227 & 2,26 \\
\hline 20 & Apriyeni & 50.881 .610 & 50.881 .610 & 15,69 & 226 & 230 & 2,29 \\
\hline 21 & Erlena & 54.271 .790 & 54.271 .790 & 14,51 & 228 & 232 & 2,31 \\
\hline 22 & Iwan & 52.210 .000 & 52.210 .000 & 15,14 & 227 & 229 & 2,28 \\
\hline 23 & Pamela Susanti & 62.260 .000 & 62.260 .000 & 17,75 & 233 & 236 & 2,35 \\
\hline 24 & Hapni & 54.274 .960 & 54.274 .960 & 13,49 & 229 & 231 & 2,30 \\
\hline 25 & Era Mayasopa & 49.485 .430 & 49.485 .430 & 15,63 & 221 & 226 & 2,25 \\
\hline 26 & Nazomi Firdaus & 49.731 .760 & 49.731 .760 & 16,23 & 222 & 228 & 2,27 \\
\hline 27 & Husaini & 50.317 .700 & 50.317 .700 & 17,68 & 225 & 231 & 2,30 \\
\hline
\end{tabular}

Sumber: Dispora Kab Muara Jambi

Dari data diatas pak Husaini selaku staf pelaksana di Dinas Pariwisata pemuda dan olahraga Kabupaten Muaro Jambi bahwa persentase Tingkat perkembangan pendapatannya lebih besar dari persentase Tingkat perkembangan pendapatan kepala dinas yang mana pada saat itu saya melakukan wawancara kepada beliau bahwa hal yang menyebabkan tingginya persentase Tingkat perkembangan pendapatan beliau antara lain disebabkan oleh :

(1) Keuletannya dalam bekerja

(2) Tidak Pamrih dalam melaksanakan perintah dari atasan

(3) Rajin dalam melaksanakan tugas

(4) Disiplin

(5) Dan banyak pegawai yang jabatannya lebih tinggi dari beliau yang meminta bantuannya dengan memberikan jasa tambahan. 
Tingkat perkembangan pendapatan ini tidak berarti bahwa pendapatan staf melebihi pendapatan kepala dinas. Hal ini terlihat dengan jelas bahwa Tingkat perkembangan itu di hitung dari besarnya rasio jumlah pendapatan yang diterimanya selama satu tahun di bandingkan jumlah pendapatannya tahun sebelumnya. Demikian juga persentase Tingkat Perkembangan Kehadiran pegawai pada seluruhnya diatas angka 2,20\% dan hasil perkembangan tingkat kehadiran antara satu dan yang lainnya hanya memiliki perbedaan yang sedikit, yang mana perentase tingkat kehadiran yang paling tinggi adalah 2,40\% dan yang terendah yaitu $2,25 \%$

\section{Besarnya Pendapatan Pegawai Terhadap Tingkat Kehadiran Pegawai di Dinas Pariwisata Pemuda dan Olahraga Kabupaten Muaro Jambi.}

Menurut (Flippo, 2013) Besarnya Pendapatan yang diperoleh pegawai mencerminkan jabatan, status, kedisiplinan dalam hal kehadiran dan tingkat pemenuhan kebutuhan yang dinikmatinya bersama keluarga. Apabila Pendapatan yang diterima semakin besar, maka kedisiplinan kerja dalam hal kehadiran semakin baik, statusnya semakin baik pula. Dengan demikian hasil kerja akan semakin baik.

Untuk mengetahui hasil dari penelitian tentang pengaruh besarnya pendapatan pegawai terhadap tingkat kehadiran pegawai dapat dilihat pada tabel dibawah ini:

Tabel.2. Besarnya pendapatan pegawai dan tingkat kehadiran pegawai di Dinas pariwisata pemuda dan olahraga kabupaten Muaro Jambi Tahun 2018

\begin{tabular}{|r|l|r|r|r|}
\hline \multirow{2}{*}{$\begin{array}{c}\text { N } \\
\mathrm{o}\end{array}$} & Nama & Jumlah Pendapatan & \multicolumn{2}{|c|}{ Tingkat kehadiran } \\
\cline { 3 - 5 } & & & \multicolumn{1}{|c|}{ Jumlah } & \multicolumn{1}{|c|}{ Persentase } \\
\hline 1 & Drs.Indra Gunawan & 117.725 .336 & 241 & 97,57 \\
\hline 2 & M. Hafis H. I.,SE & 88.926 .934 & 239 & 96,76 \\
\hline 3 & Supri Hardi, SE & 80.366 .178 & 237 & 95,95 \\
\hline 4 & M. Iqbal, SE, ME & 79.471 .492 & 236 & 95,54 \\
\hline 5 & Hatimah, SE & 88.613 .594 & 239 & 96,76 \\
\hline 6 & Eti Supriani, S.STP & 69.280 .444 & 236 & 95,54 \\
\hline 7 & Azwan, S.Ag & 83.399 .136 & 238 & 96,35 \\
\hline 8 & Herman Susilo, SE & 80.696 .408 & 237 & 95,95 \\
\hline 9 & Aswar Muda & 76.149 .178 & 236 & 95,54 \\
\hline 10 & Deni Eriyanti, S.SN & 69.309 .100 & 235 & 95,14 \\
\hline 11 & Robi Irwanada, SE. M.Sc & 72.268 .500 & 235 & 95,14 \\
\hline 12 & Dedi Ismet, S.Pdi & 72.174 .486 & 235 & 95,14 \\
\hline 13 & Saadah, SE & 64.124 .150 & 233 & 94,33 \\
\hline 14 & Fahrur Rozi & 72.034 .586 & 235 & 95,14 \\
\hline 15 & Siska Herlina & 60.320 .700 & 231 & 93,52 \\
\hline 16 & BayuYudha Pratama, S.STP & 62.313 .640 & 232 & 93,92 \\
\hline 17 & Hajri & 77.040 .610 & 237 & 95,95 \\
\hline
\end{tabular}




\begin{tabular}{|l|l|r|r|r|}
\hline 18 & Wenti Anggraini & 67.420 .296 & 234 & 94,73 \\
\hline 19 & Salina, A.Md & 57.572 .610 & 227 & 91,90 \\
\hline 20 & Apriyeni & 58.866 .026 & 230 & 93,11 \\
\hline 21 & Erlena & 61.876 .718 & 232 & 93,92 \\
\hline 22 & Iwan & 60.114 .928 & 229 & 92,71 \\
\hline 23 & Pamela Susanti & 73.314 .928 & 236 & 95,54 \\
\hline 24 & Hapni & 61.597 .472 & 231 & 93,52 \\
\hline 25 & Era Mayasopa & 57.507 .942 & 226 & 91,49 \\
\hline N & Nama & Jumlah Pendapatan & \multicolumn{2}{|c|}{ Tingkat kehadiran } \\
\cline { 3 - 5 } o & & & Jumlah & Persentase \\
\hline 26 & Nazomi Firdaus & 57.805 .040 & 228 & 92,30 \\
\hline 27 & Husaini & 59.217 .754 & 231 & 93,52 \\
\hline
\end{tabular}

Sumber : Data Olahan Hasil Penelitian Tahun 2019

Dari data diatas dapat dijelaskan bahwa tingkat rata-rata persentase kehadiran pegawai yaitu diatas 90\%. Dan dari tabel diatas juga terlihat jelas bahwa pegawai yang memiliki pendapatan yang cukup rendah mempengaruhi rendahnya dalam hal kehadiran seperti pada tabel 2 di Nomor.25 jumlah pendapatan keseluruhan yang diperoleh yaitu Rp.57.507.942 dengan jumlah kehadiran 226 hari. Dan sebaliknya bahwa pegawai yang memiliki besar pendapatan yang tinggi akan berpengaruh terhadap tingkat kehadirannya seperti pada Nomor.1 sebesar Rp.117.725.336 dengan jumlah kehadiran 241 hari yang merupakan pendapatan dan tingkat kehadiran yang paling tinggi dibandingkan yang lain.

\section{Analisis Data}

\section{Hasil Uji Validitas dan Uji Reliabilitas Instrumen}

a) Uji Validitas

Uji validitas dilakukan untuk mengukur sah atau tidaknya indikator atau kuesioner dari masing-masing variabel. Pengujian dilakukan dengan membandingkan $\mathrm{r}$ hitung dan rtabel. Nilai rhitung merupakan hasil korelasi jawaban responden pada masing-masing pertanyaan disetiap variabel yang dianalisis dengan program spss dan outputnya bernama corrected item correlation. Sedangkan untuk mendapatkan $\mathrm{r}$ tabel dilakukan dengan tabel $\mathrm{r}$ product moment, yaitu menentukan $\alpha=0,05$ kemudian $n=25$ sehingga didapat nilai rtabel dua sisi sebesar 0,396 . Tingkat kevalidan indikator atau kuesioner dapat ditentukan, apabila rhitung $>$ rtabel $=$ Valid dan rhitung $<$ rtabel $=$ Tidak Valid. Hasil uji validitas selengkapnya dapat dilihat pada tabel berikut:

Tabel.3. Hasil Uji Validitas Instrumen

\begin{tabular}{|c|c|c|c|}
\hline Item & $\begin{array}{c}\text { Corrected itemtotal } \\
\text { correlation } \\
\text { (r hitung) }\end{array}$ & $\mathrm{r}$ tabel & Keterangan \\
\hline
\end{tabular}




\begin{tabular}{|c|c|c|c|}
\hline \multicolumn{4}{|c|}{ Variabel : Pendapatan Pegawai(X) } \\
\hline Gaji Pokok & 0,749 & 0,396 & VALID \\
\hline Tunjangan & 0,822 & 0,396 & VALID \\
\hline TPP & 0,650 & 0,396 & VALID \\
\hline Pendapatan lainnya & 0,704 & 0,396 & VALID \\
\hline \multicolumn{3}{|c|}{ Variabel Tingkat Kehadiran Pegawai(Y) } \\
\hline Jumlah Hari & 0,688 & 0,396 & VALID \\
Kehadiran & 0,763 & 0,396 & VALID \\
\hline Tingkat Kehadiran &
\end{tabular}

Sumber: Hasil Pengolahan Data Primer dengan SPSS, 2019.

Terlihat dari Tabel di atas bahwa nilai rhitung pada kolom corrected itemtotal correlation untuk masing-masing item memiliki rhitung lebih besar dan positif dibanding rtabel, maka dapat disimpulkan bahwa untuk kedua variabel $\mathrm{X}$ dan $\mathrm{Y}$ adalah valid.

b) Uji Reliabilitas

Uji Reliabilitas adalah tingkat ke andalan kuesioner. Kuesioner yang reliabel adalah kuesioner yang apabila digunakan secara berulang-ulang kepada kelompok yang sama akan menghasilkan data yang sama. Asumsinya, tidak terdapat perubahan psikologis pada responden. Memang, apabila data yang diperoleh sesuai dengan kenyataannya, berapa kalipun pengambilan data dilakukan, hasilnya tetap sama (Simamora, 2004:177).

Menurut Ghozali (2011:308) Suatu instrumen dikatakan handal (reliabel) bila memiliki koefisien kehandalan (Alpha Cronbach) sebesar 0,6 atau lebih. Jadi jika nilai reliabilitas $>$ nilai Alpha Cronbach $(0,6)$, maka butir kuesioner dikatakan reliabel.

Adapun hasil uji reliabilitas dari data yang peneliti gunakan sebagai berikut:

Tabel.4. Rekapitulasi Hasil Uji Reliabilitas

\begin{tabular}{|l|c|c|}
\hline Variabel & Koefisien Alpha & Keterangan \\
\hline Pendapatan Pegawai (X) & 0,863 & Reliabel \\
\hline Tingkat Kehadiran Pegawai (Y) & 0,821 & Reliabel \\
\hline
\end{tabular}

Berdasarkan data dari tabel diatas menunjukkan bahwa variabel independen dan variabel dependen dapat dikatakan reliabel karena nilai alpha $>$ Alpha cron bach $(0,6)$. Dengan demikian dapat disimpulkan bahwa data yang diteliti dalam penelitian ini sudah respentatif, dalam arti pengukuran datanya dapat di percaya.

\section{Hasil regresi Linear Sederhana}

Hasil dari analisis regresi sederhana diperoleh output data seperti pada tabel berikut :

Tabel.5. Hasil Regresi

\begin{tabular}{|l|c|}
\hline \multicolumn{2}{|c|}{ Coefficients $^{\mathrm{a}}$} \\
\hline Model & Unstandardized Coefficients $^{2}$ \\
\hline
\end{tabular}




\begin{tabular}{|l|l|r|rr|}
\hline \multicolumn{2}{|c|}{} & \multicolumn{1}{|c|}{ B } & \multicolumn{2}{c|}{ Std. Error } \\
\hline \multirow{2}{*}{1} & (Constant) & 21,772 & \multicolumn{2}{c|}{3,176} \\
\cline { 2 - 5 } & Pendapatan Pegawai &, 650 & & 063 \\
\hline
\end{tabular}

a. Dependen variable : Tingkat Kehadiran Pegawai

Berdasarkan output yang ditunjukkan oleh tabel diatas diketahui nilai constant (a) sebesar 21,772 sedangkan nilai Besarnya pendapatan peawai (b) sebagai koefisien regresi sebesar 0,650 , sehingga persamaan regresinya dapat ditulis sebagai berikut :

$$
\begin{aligned}
& \mathrm{Y}=\alpha+\beta \mathrm{X}+\varepsilon \\
& \mathrm{Y}=21,772+0,650 \mathrm{X}
\end{aligned}
$$

Dengan keterangan :

$\mathrm{Y}=$ tingkat kehadiran pegawai

$\mathrm{X}=$ pendapatan pegawai

$\alpha=$ konstanta

$\beta=$ koefisien regresi

$\mathcal{E}=$ faktor kesalahan (asumsi $=0)$

Hasil analisis tersebut akan di interpretasikan sebagai berikut :

a. Konstanta sebesar 21,772 mengandung arti bahwa jika variabel Pendapatan pegawai diabaikan atau bernilai nol, maka nilai variabel Tingkat Kehadiran sebesar 21,772\%, dan dipengaruhi variabel lain.

b. Koefisien regresi sebesar 0,650 mengandung arti bahwa setiap penambahan 1 poin nilai Pendapatan Pegawai, maka nilai Tingkat Kehadiran bertambah 0,650. Koefisien regresi tersebut bernilai positif, sehingga dapat dikatakan bahwa arah pengaruh variabel $\mathrm{X}$ terhadap Y adalah positif.

\section{Uji Normalitas}

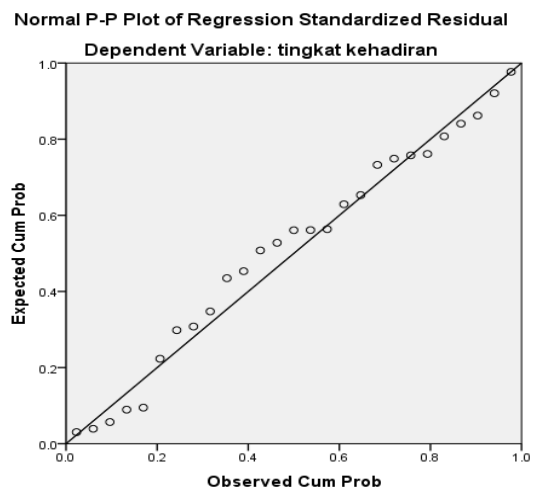


Hasil uji normalitas dapat dilihat pada grafik plot sebagai berikut:

Dari grafik tersebut tampak bahwa tiitik-titik menyebar disekitar garis diagonal dan mengikuti arah garis diagonal, maka model regresi memenuhi asumsi normalitas yang berarti data telah terdistribusi normal.

\section{Uji $\mathbf{R}^{2}$ Koefisien Determinasi}

Nilai dari koefisien determinasi digunakan sebagai sumbangan pengaruh yang diberikan oleh variabel bebas $(\mathrm{x})$ terhadap variabel terikat (y). Nilai koefisien determinasi dipakai untuk memprediksi seberapa besar kontribusi pengaruh variabel Pendapatan Pegawai terhadap variabel Tingkat Kehadiran pegawai dengan syarat, hasil uji tharus signifikan.

Tabel.6. Hasil Uji R Square

\begin{tabular}{|l|c|r|c|c|}
\hline Model & $\mathrm{R}$ & $\mathrm{R}$ Square & $\begin{array}{c}\text { Adjusted R } \\
\text { Square }\end{array}$ & $\begin{array}{c}\text { Std. Error of the } \\
\text { Estimate }\end{array}$ \\
\hline 1 &, $880^{\mathrm{a}}$ &, 775 &, 766 &, 75671 \\
\hline
\end{tabular}

a. Predictors: (Constant), Pendapatan Pegawai

b. Dependent Variable: TINGKAT KEHADIRAN PEGAWAI

Hasil uji R square yang ditunjukkan pada tabel 5.16 diatas menjelaskan bahwa nilai $\mathrm{R}$ Square menunjukkan angka $0,775=77,5 \%$. Angka tersebut mengandung arti bahwa pendapatan pegawai berpengaruh terhadap tingkat kehadiran pegawai sebesar 77,5\%. Sedangkan sisanya yakni $(100 \%-77,5 \%=22,5 \%)$ dipengaruhi oleh variabel lain diluar model ini.

\section{Uji Hipotesis}

\section{Uji Parsial (Uji t)}

Uji parsial atau uji t digunakan ntuk menyelidiki masing-masing variabel bebas yang berpengaruh secara signifikan terhadap tingkat kehadiran. Hasil uji t dapat dilihat pada tabel.7. sebagai berikut:

\begin{tabular}{|l|l|r|r|}
\hline Model & T & \multicolumn{2}{|c|}{ Sig. } \\
\hline 1 & (Constant) & 6,906 & \multicolumn{2}{c|}{, 000} \\
\hline & Pendapatan Pegawai & 8,774 &, 000 \\
\hline
\end{tabular}

Dependent Variable: Tingkat Kehadiran Pegawa

Sumber : Data Olahan SPSS

Berdasarkan nilai signifikansi dari tabel Coefficients yang ditunjukkan oleh tabel 5.17 diperoleh nilai signifikansi sebesar $0,000<0,05$, sehingga dapat disimpulkan bahwa variabel Besarnya Pendapatan (x) berpengaruh terhadap variabel Tingkat kehadiran (y). Nilai tabel terletak pada nomor 25 pada distribusi nilai tabel pada lampiran. Dan berdasarkan nilai t, 
diketahui nilai thitung sebesar 8,774>2,060, sehingga dapat disimpulkan bahwa variabel Besarnya pendapatan (x) berpengaruh terhadap variabel Tingkat Kehadiran (y). Pada analisis uji-t pada tabel 5.18 nilai thitung sebesar 8,774, sementara itu nilai tabel distribusi $0,05(5 \%)$ sebesar 2,060 maka thitung $>$ tabel dan nilai signifikansi yaitu $0,000<0,05$, berdasarkan angka diatas, dapat disimpulkan bahwa variabel besarnya pendapatan (X) berpengaruh positif dan signifikan terhadap tingkat kehadiran pegawai.

\section{Analisis Pengaruh Besarnya Pendapatan Pegawai Terhadap Tingkat Kehadiran Pegawai di Dinas Pariwisata Pemuda Dan Olahraga Kabupaten Muaro Jambi}

Untuk memenuhi kebutuhan sehari-hari, manusia harus bekerja untuk memenuhi kebutuhannya tersebut baik itu kebutuhan jasmani maupun kebutuhan rohani. Kebutuhan jasmani adalah kebutuhan akan barang yang dibutuhkan seperti sandang, papan, dan pangan. Untuk memenuhi kebutuhan tersebut manusia bekerja siang dan malam hanya untuk mendapatkan uang atau upah dari pekerjaan yang dilakukan. Semakin besar Pendapatan yang mereka peroleh maka semakin besar kebutuhan mereka akan terpenuhi dan begitu sebaliknya pemberian pendapatan yang sedikit membuat pegawai tersebut malas dalam bekerja dan lalai dalam menjalankan pekerjaannya.

Dalam penelitian ini membuktikan bahwa Pengaruh besarnya pendapatan pegawai terhadap tingkat kehadiran pegawai di dinas pariwisata pemuda dan olahraga kabupaten Muaro Jambi, dapat di lihat dari model regresi sebagai berikut :

$$
\mathrm{Y}=21,772+0,650 \mathrm{X}
$$

Hasil uji parsial diatas memperlihatkan bahwa thitung $>$ ttabel. Hal ini menunjukan bahwa semakin besar tingkat pendapatan pegawai semakin tinggi tingkat kehadiran pegawai. Dan dalam hal ini dikuatkan juga oleh teori dari (Handoko, 2002) yang mengatakan faktor pendorong yang menyebabkan manusia bekerja adalah adanya kebutuhan dalam diri manusia yang harus dipenuhi dengan kata lain, berangkat dari keinginan untuk memenuhi kebutuhan hidup, manusia menjual tenaga, pikiran dan juga waktu yang dimilikinya dengan harapan mendapatkan pendapatan yang lebih.

Besarnya Pendapatan yang diperoleh pegawai mencerminkan jabatan, status dan tingkat pemenuhan kebutuhan yang dinikmatinya bersama keluarga. Apabila Pendapatan yang diterima semakin besar, kedisiplinan dalam hal kehadiran semakin baik, statusnya semakin baik pula. Dengan demikian hasil kerja akan semakin baik. 


\section{KESIMPULAN DAN SARAN}

\section{Kesimpulan}

1. Perkembangan tingkat pendapatan pegawai dan tingkat kehadiran pegawai. Perkembangan tingkat pendapatan pegawai dan tingkat kehadiran pegawai dapat disimpulkan sebagai berikut :

a. Perkembangan tingkat pendapatan

Rata-rata perkembangan tingkat pendapatan pegawai pada periode 2015 \& 2018 adalah $15,51 \%$.

b. Perkembangan tingkat kehadiran

Rata-rata perkembangan tingkat kehadiran pegawai pada periode 2015 \& 2018 adalah $2,33 \%$.

2. Besarnya pendapatan pegawai terhadap tingkat kehadiran pegawai.

a. Uji parsial memperlihatkan bahwa thitung $>$ ttabel. Model regresi ini membuktikan bahwa semakin Besar pendapatan maka semakin tinggi pula tingkat kehadiran.

b. Terdapat hubungan yang positif signifikan antara Besarnya Pendapatan Pegawai dengan Tingkat Kehadiran Pegawai di Dinas Pariwisata Pemuda Dan Olahraga Kabupaten Muaro Jambi, dimana R Square nya sebesar 0,775.

\section{Saran}

Hasil penelitian memperlihatkan bahwa ada hubungan dan pengaruh antara besarnya pendapatan pegawai dan tingkat kehadiran pegawai. Oleh karena itu :

1) Dinas pariwisata pemuda dan olahraga kabupaten Muaro Jambi melalui pemerintah kabupaten perlu dengan sungguh-sungguh meningkatkan kesejahteraan pegawai dengan menambah jumlah pendapatan pegawai yang disiplin terutama dalam hal kehadiran.

2) Dinas pariwisata pemuda dan olahraga kabupaten Muaro Jambi perlu memberikan penghargaan kepada pegawai yang konsisten meningkatkan disiplin kerja yang tidak semata-mata di ukur dari besarnya materi yang diterimanya.

\section{DAFTAR PUSTAKA}

Ari Kunto, Prof. Dr. Suharsimi. 2000. Manajemen Penelitian. Jakarta : PT. Rineka Cipta. Arfida BR. 2003. Ekonomi Sumber Daya Manusia. Jakarta : Ghalia Indonesia. 
Ahmad, Faisal Ali. 2006. Mengolah dan membuat interpretasi hasil olahan SPSS untuk penelitian ilmiah. Jakarta : Penerbit Edsa Mahkota.

Adisu, Edytus. 2008. Hak Karyawan Atas Gaji dan Pedoman Menghitung Gaji. $\quad$ Jakarta: Forum Sahabat.

BN. Marbun. 2003. Manajemen Sumber Daya Manusia. Jakarta : Pustaka Sinar Harapan.

Dessrel, Gery. 2008. Human Resource Management., Edisi Sebelas, New Jersey : Pearson Education, Inc.

Edwin B. Flippo. 2013. Personel Management (Manajemen Personalia). Jakarta : Edisi.VII Jilid II. Terjemahan Alponso S, Erlangga.

Ghozali, Imam. 2005. Aplikasi multivariate SPSS. Semarang : badan Penerbit UNDIP.

Gie Nurani. 2013. Manajemen Sumber Daya Manusia, Yayasan Aini Syam : Pekanbaru.

Handoko. 2001. Manajemen Personalia dan Sumber Daya Manusia edisi I. Palu : Asset. .2011. Manajemen Personalia dan Sumber Daya Manusia edisi II. Yogyakarta : BPFE. Cetakan ke lima belas.

Jogiyanto. 2005. Manajemen Sumber Daya Manusia, Makassar : Pustaka.

Luthans, Fredh. 2006. Perilaku Organisasi. Yogyakarta : Andil.

Moeijat. 2002. Manajemen Tenaga Kerja Dan Hubungan Kerja. Bandung : Pionir.

Malayu S.P Hasibuan. 2010. Manajemen Sumber Daya Manusia. Jakarta : Bumi Aksara.

Malhotra. 2006. Reliabilitas dan Validitas. Yogyakarta: Pustaka Pelajar.

Muhdarsyah Sinungan. 2009. Produktifitas Apa Dan Bagaimana. Jakarta : Bumi Aksara.

Nazir. 2010. Metode Penelitian. Produksi Ghalia Indonesia : Bogor.

Nitisemito. 2004. Manajemen Personalia. Ghalia Indonesia : Jakarta.

Rekso prayitno. 2004. Sistem Ekonomi Dan Demokrasi Ekonomi. Jakarta : Bina Grafika.

Rivai , Veitzhal. 2009. Manajemen Sumber Daya Manusia Untuk Perusahaan Dari Teori Ke Praktik. Jakarta : Raja Grafindo Persada.

Romney dan steinbart. 2006. Accounting Information System. Jakarta : Prentice Hall.

Sadorno . 2006. Mikro Ekonomi Teori Pengantar. Jakarta : Raja Agrafindo. 
Sutrisno Edi. 2009. Manajemen Sumber Daya Manusia. Jakarta : Kencana Prenada Media Grup.

Sedarmayanti. 2009. Sumber Daya Manusia Dan Produksi Kerja. Bandung : Mandar Maju.

Soekarwati . 2002. Faktor-Faktor Produksi. Jakarta : Salemba Empat.

Simamora . 2004. Manajemen Sumber Daya Manusia, Yogyakarta : STIE YKPN.

Samsudin . 2009. Manajemen Perusahaan. Jakarta : PT. Raja Grafindo.

Sugiyono. 2001. Metode Penelitian, Bandung: CV Alfa Beta. .2006. Metode Penelitian Bisnis. Bandung: Alfabeta. . 2012. Metode Penelitan Kuantitatif Kuaitatif dan R\&D. Bandung : Alfabeta.

\section{Dokumen-dokumen}

Peraturan Daerah Kabupaten Muaro Jambi Nomor 17 Tahun 1999 tentang Susunan Organisasi dan Tata Kerja Pemerintah Daerah Kabupaten Muaro Jambi.

Keputusan Kepala Lembaga Administrasi Daerah (LAD) Nomor, 239/IX/6/8/2003 tentang Pedoman Teknis Pelaksanaan Sistem Akuntabilitas Kinerja Instansi Pemerintah (AKIP).

Peraturan Pemerintah No. 26 Tahun 2007 tentang Tunjangan Jabatan struktural

Peraturan Pemerintah No. 8 Tahun 2009 tentang Besaran gaji pokok pegawai.

Peraturan Mentri Dalam Negri Republik Indonesia Nomor 4 tahun 2013 tentang Jam kerja Pegawai instansi Pemerintah. 